\title{
An Examination on Production and Marketing of Cotton in Srivilliputtur Taluk
}

\section{P.Ramakrishnan}

\begin{abstract}
Agriculture to-day occupies a very important and unique place in the economy of India. It promotes rural employment, income level and enhances the socioeconomic status of the farmers. In short, agriculture in India not only decides the economy of the country but also determines its Industrial development. There are many kinds of agricultural products produced in India like Cotton, Paddy, Wheat, and Sugarcane etc. Agricultural marketing involves many operations and processes through which the food and raw materials move from the farm to the final consumers. Hence the researcher is intended to identify the existing and emerging prospects in cultivation and production of Cotton in Srivilliputtur Taluk as well as to analyze the emanated and enlarging problems in marketing of Cotton to arrive at appropriate authentication and respective rejuvenation.
\end{abstract}

Keywords: Agriculture, Cotton, manufacturer, marketing, Cultivation

\section{INTRODUCTION}

Cotton is a commodity having global economic significance. It is an income and employment generating crop. Cotton and textiles, being one of the dominant sectors of Indian economy, they sustain directly and indirectly the livelihood of about seven million people.

India has the largest area under cotton cultivation and shares about $24 \%$ of world cotton average and $12 \%$ of the world production. India maintains its position as the third largest cotton producer next to China and U.S.A. As a user India accounts far for nearly one-tenth of world cotton consumption. No other cash crop in India can compete with cotton's potential in processing for value added products and exports cotton deserves special attention in an agricultural policy planning. Opportunity for India to increase its cotton based production and export of cotton based products is very bright.

In many developing countries, cotton is an important agricultural commodity. Cotton is generally referred to as "WHITE GOLD" and its cultivation and making give employment to thousands people besides earning foreign exchange for the country. In India over 60 million people derive Income from the cotton/textile sector and Indian textile Industry accounts for 20 percent of Industrial output and contributes nearly one - third of the textile exports.

\section{IMPORTANCE OF THE STUDY}

Cotton is one of the most important commercial crops in India. But its production is concentrated mainly

Revised Manuscript Received on December 09, 2019.

Mr. P. Ramakrishnan*, Assistant Professor, Department of Commerce Kalasalingam Academy of Research and Education Krishnankoil, Tamilnadu, India. Email: ramkhansai@gmail.com in nine States namely Andhra Pradesh, Gujarat, Haryana, Karnataka, Mathya Pradesh, Maharashtra, Punjab, Rajasthan and Tamilnadu- these States together accounts for about 99 percent of the total area under cotton. India is the only country in the world that grows all the four cultivated cotton species, viz.

G. Hirsutum, G. arboretum, G, harbaceum and G. barbaense. On the basis of agro-climatic condition the country is divided into three major cotton growing zones, the Northern comprising the states of Punjab, Hariyana and Rajasthan, accounting about 1663 thousand hectare, the central consisting of Gujarat, Madhya Pradesh and Maharashtra the Major cotton producing region, accounting for 4267 thousand hectare and the southern comprising of Andhra Pradesh, Karnataka, Tamilnadu and accounting for about 1644 thousand hectare.

\section{STATEMENT OF THE PROBLEM}

The cotton cultivators are facing innumerable problems like inadequate financial facilities from the commercial banks, lack of information regarding the market price, inadequate and poor storage facilities and so on. They also face transportation problem. The increased cultivation cost has reduced the profitability of cotton cultivations.

There is no organization and co-operation among the cultivators. So, the village traders are exploiting, by fixing the prices far below the cost of production. Moreover, the services of regulated markets are also used negligible level by the cotton cultivators. Thus, on the marketing side also they face more problems like.

1. Insufficiency of production compared to demand.

2. Seasonality of production

The quantity and quality of the price are fixed by the middle man not by the cultivators. Selection and control of the channel of distribution also lie in the hands of intermediaries. These peculiar features make agricultural marketing mostly disorganized. Hence there is an imperative need to undertake a comprehensive and empirical study of this nature in the study area.

\section{OBJECTIVES OF THE STUDY}

The objectives of the study are as follows,

1. To identify the role and importance of cotton in the agricultural production of India.

2. To ascertain the cultivation practices and problems in the cultivation of cotton.

3. To analyze weather conditions which are affecting the yield of

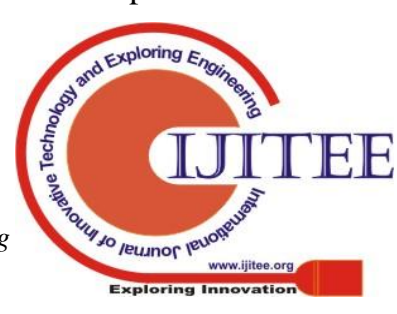


cotton?

4. To offer suitable suggestions on the basis of the findings of the study.

\section{SCOPE OF THE STUDY}

In the study area the soil is more suitable for cultivation of cotton. In and around the Srivilliputtur more number of villages are cultivating in cotton in considerable quantity. Further Srivilliputtur has a cotton research centre which was established in 1950 itself, and also famous for vegetable market.

Number of mills functioning in the Virudhunagar district, particularly in Rajapalayam and in and around the Srivilliputtur area exhibits that the importance of cultivation of cotton in the study area.

The present study covers the cultivation practices and the marketing problems faced by cotton cultivators, village Traders and Commission Agents, in Srivilliputtur Taluk. The researcher has also studied the role of village traders and commission agents in the marketing of cotton. The cotton crop is cultivated in irrigated and non-irrigated lands. The researcher has analyzed the production of cotton in irrigated land only.

\section{METHODOLOGY}

The necessary data are collected from both the primary and secondary sources.

\section{PRIMARY DATA}

A well structured interview schedule has been prepared. This interview schedule has been used for getting required data from the cotton cultivators.

\section{SECONDARY DATA}

Secondary data has been collected from various sources like published Books, Journals, Government reports and Records of regulated markets etc.

\section{SAMPLING DESIGN}

In the study area 500 farmers are cultivating cotton. The researcher has selected $10 \%$ by applying Simple Random Sampling Technique. As a result data collected from 50 cultivators for the present study.

\section{STATISTICAL TOOLS}

Analyses and interpretation of data will be made with the help of following statistical tools.

\section{* Percentage \\ * Chi-square test.}

\section{AREA COVERED}

For the purpose of the study Srivilliputtur of the Virudhunagar District has been selected. In Srivilliputtur Taluk the farmers cultivate the cotton as a main crop. Srivilliputtur area is selected for his study because the researcher is belonging to this area. This study covers the entire areas of Srivilliputtur.

\section{OWNERSHIP OF LAND}

The researcher has analyzed the ownership of land of the respondents. The gathered details are presented in the following table

TABLE-1

OWNERSHIP OF LAND

\begin{tabular}{|c|l|c|c|}
\hline S. No. & Particulars & $\begin{array}{c}\text { No. of. } \\
\text { Respondents }\end{array}$ & $\begin{array}{c}\text { Percenta } \\
\text { ge of } \\
\text { Total }\end{array}$ \\
\hline 1. & Own & 25 & 50 \\
\hline 2. & Hired & 10 & 20 \\
\hline 3. & Both & 15 & 30 \\
\hline & Total & $\mathbf{5 0}$ & $\mathbf{1 0 0}$ \\
\hline
\end{tabular}

Source: Primary Data

From the above table it is clear that, $50 \%$ of the farmers are having own land and $20 \%$ of the farmers having Hired land and the remaining $30 \%$ of the farmers are cultivating the cotton in both own and hired Land.

From the above analysis it is revealed that most of the farmers are cultivating cotton on the own land.

\section{CULTIVATION OF COTTON}

The following table shows the details of cultivation of cotton in the land owned by the farmers.

TABLE-2

CULTIVATION OF COTTON

\begin{tabular}{|c|c|c|c|}
\hline $\begin{array}{c}\text { S. } \\
\text { No. }\end{array}$ & Particulars & $\begin{array}{c}\text { No. of } \\
\text { Respondents }\end{array}$ & Percentage \\
\hline 1. & Cultivate & 35 & 70 \\
\hline 2. & Uncultivated & 15 & 30 \\
\hline & Total & $\mathbf{5 0}$ & $\mathbf{1 0 0}$ \\
\hline
\end{tabular}

Source: Primary Data

From the above table it is known that $70 \%$ of the respondents cultivate the cotton throughout the year and the remaining $30 \%$ of the respondent does not cultivate the cotton throughout the year.

From the above analysis it is understood that (70\%) of the respondents are cultivating cotton in throughout the year.

\section{SEASON FOR CULTIVATION OF COTTON}

To ascertain the suitability of the period of cotton cultivation, study has been made. The following table 3 gives the details regarding the season for cotton cultivation.

TABLE - 3

SEASON FOR COTTON CULTIVATION

\begin{tabular}{|c|c|c|c|}
\hline $\begin{array}{c}\text { S. } \\
\text { No. }\end{array}$ & Season & $\begin{array}{c}\text { No. of } \\
\text { Respondents }\end{array}$ & Percentage \\
\hline 1. & Summer & 40 & 80 \\
\hline 2. & Winter & 10 & 20 \\
\hline & Total & $\mathbf{5 0}$ & $\mathbf{1 0 0}$ \\
\hline
\end{tabular}

Source: Primary Data

Accordingly, the season for cultivation the cotton may be divided into two namely summer season and winter season. Even though there are two seasons for cultivation, in the researcher has identified 
them $80 \%$ of the respondents cultivate the cotton in summer season and the remaining $20 \%$ of the respondents cultivate the cotton in winter season.

It is interesting to note that most $(80 \%)$ of the respondents prefer summer season for cotton cultivation in the study area.

\section{TESTING HYPOTHESIS}

Generally, the weather condition is a determinant factor for any agricultural production rather than factors like market conditions. To prove this statement the researcher has framed the following hypothesis that,

"The season for cotton cultivation is playing a dominant role in yield of cotton per acre in the study area"

To test the above hypothesis, the researcher has used the chi-square test. The following table represents the fact.

\section{OBSERVED FREQUENCY YIELD TO COTTON}

\begin{tabular}{|c|c|c|c|}
\hline Season & Affected & Not affected & Total \\
\hline Summer & 15 & 25 & 40 \\
\hline Winter & 4 & 6 & 10 \\
\hline Total & $\mathbf{1 9}$ & $\mathbf{3 1}$ & $\mathbf{5 0}$ \\
\hline
\end{tabular}

Source: Primary Data

EXPECTED FREQUENCY YIELD TO COTTON

\begin{tabular}{|c|c|c|c|}
\hline Season & Affected & Not affected & Total \\
\hline Summer & 13 & 26 & 39 \\
\hline Winter & 6 & 5 & 11 \\
\hline Total & $\mathbf{1 9}$ & $\mathbf{3 1}$ & $\mathbf{5 0}$ \\
\hline
\end{tabular}

Source: Primary Data

\section{CALCULATION OF CHI-SQUARE}

\begin{tabular}{|c|c|c|c|c|}
\hline $\mathbf{O}$ & $\mathbf{E}$ & $\mathbf{O - E}$ & $(\mathbf{O - E})^{\mathbf{2}}$ & $\begin{array}{c}(\mathbf{O - E}) \\
\mathbf{2} \mathbf{E}\end{array}$ \\
\hline 15 & 13 & 2 & 4 & 1.23076 \\
\hline 25 & 26 & 1 & 1 & 0.03846 \\
\hline 4 & 6 & 2 & 4 & 1.23076 \\
\hline 6 & 5 & 1 & 1 & 0.03846 \\
\hline \multicolumn{5}{|l}{} \\
\hline
\end{tabular}

Source: Primary Data

$\sum=(0-\mathrm{E})^{2} / \mathrm{E}$

$=2.53844$

Degrees of freedom $=(\mathrm{R}-1)(\mathrm{C}-1)$

$=(2-1)(2-1)=1$.

For 1 degrees of freedom @ 5\% level of significance is 3.841.

Hence, the calculated value is less than the table Value the hypothesis is accepted. It is proved that the season for cotton cultivation is playing a dominant role in yield of cotton per acre in the study area.

TABLE -4

PROBLEMS OF COTTON CULTIVATION

\begin{tabular}{|c|l|c|c|}
\hline $\begin{array}{c}\text { S. } \\
\text { No. }\end{array}$ & \multicolumn{1}{|c|}{ Problems } & $\begin{array}{c}\text { No. of } \\
\text { Respondents }\end{array}$ & Percentage \\
\hline 1. & Bad climate & 13 & 26 \\
\hline 2. & Lack of finance & 25 & 50 \\
\hline 3. & Scarcity of water & 8 & 16 \\
\hline 4. & $\begin{array}{l}\text { Inadequate } \\
\text { labour }\end{array}$ & 4 & 8 \\
\hline & Total & $\mathbf{5 0}$ & $\mathbf{1 0 0}$ \\
\hline
\end{tabular}

Source: Primary Data
It is revealed from the above table $50 \%$ of the respondents are facing the lack of finance; $26 \%$ bad climate; $16 \%$ scarcity of water and the remaining $8 \%$ of the respondents are facing the problem of inadequate labour.

It is evident from the above analysis that majority of (50\%) the farmers face lack of finance, for cotton cultivation.

TABLE -5

EXPENDITURE ANALYSIS (Per Acre)

\begin{tabular}{|c|l|c|c|}
\hline S.No. & $\begin{array}{c}\text { Item of expenditure } \\
\text { (per acre) }\end{array}$ & $\begin{array}{c}\text { Amount } \\
(\text { Rs) }\end{array}$ & $\begin{array}{c}\text { Perce } \\
\text { ntage }\end{array}$ \\
\hline 1. & Ploughing & 400 & 7 \\
\hline 2. & Natural manure & 2100 & 22 \\
\hline 3. & Seeds and labour charges & 400 & 11 \\
\hline 4. & Weeding cost & 500 & 9 \\
\hline 5. & Pest control cost & 300 & 5 \\
\hline 6. & Fertilizers & 700 & 13 \\
\hline 7. & Irrigation & 450 & 8 \\
\hline 8. & $\begin{array}{l}\text { Picking charges } \\
\text { and plucking } \\
\text { charges }\end{array}$ & 2000 & 36 \\
\hline 9. & Any other chargers & 200 & 5 \\
\hline & Total & $\mathbf{5 5 0 0}$ & $\mathbf{1 0 0}$ \\
\hline
\end{tabular}

Source: Primary Data

It is clear from the above table that $5 \%$ of cost incurred for pest control; $13 \%$ of the cost for fertilizers; $11 \%$ of cost for seeds and lobour charges; $9 \%$ of the cost for weeding; $8 \%$ of cost for irrigation; $7 \%$ of cost for ploughing, $6 \%$ of cost for natural manure and the remaining $5 \%$ for other expenses.

It is clear from the above analysis that $36 \%$ the cost is incurred for picking charges and plucking charges. The above details are presented in the following diagram.

\section{TIMING OF SALE OF COTTON}

Generally speaking, growers of any product stock it till they get a remunerative price in the market. Some of them are forced to sell it immediately due to factors beyond their control. Hence the time of sale of cotton in the study area has been analyzed and the results are presented put forth in the table -6

TABLE - 6

TIMING OF SALE OF COTTON

\begin{tabular}{|c|c|c|c|}
\hline S. No. & Particulars & $\begin{array}{c}\text { No. of } \\
\text { Respondents }\end{array}$ & Percentage \\
\hline 1. & Immediately & 36 & 72 \\
\hline 2. & $\begin{array}{l}\text { Wait for } \\
\text { higher price }\end{array}$ & 14 & 28 \\
\hline & Total & $\mathbf{5 0}$ & $\mathbf{1 0 0}$ \\
\hline
\end{tabular}

Source: Primary Data

The above table clearly indicates that, $72 \%$ of formers are able to sell their produce immediately and it is interesting to note that $28 \%$ of the growers are able to wait for remunerative price.

It is cleared that from the above table indicates the $72 \%$ of the farmers to sale of cotton immediately. 


\section{INFORMATION REGARDING MARKET PRICE}

The following table shows that the various sources from which the information known regarding market price of the cotton.

TABLE - 7

SOURCES OF INFORMATION

\begin{tabular}{|c|l|c|c|}
\hline $\begin{array}{c}\text { S. } \\
\text { No. }\end{array}$ & \multicolumn{1}{|c|}{ Sources } & $\begin{array}{c}\text { No. of } \\
\text { Respondents }\end{array}$ & $\begin{array}{c}\text { Percentage } \\
\text { To total }\end{array}$ \\
\hline 1. & Through Radio & 6 & 12 \\
\hline 2. & $\begin{array}{l}\text { Through } \\
\text { Television }\end{array}$ & 9 & 18 \\
\hline 3. & $\begin{array}{l}\text { Through News } \\
\text { paper }\end{array}$ & 20 & 40 \\
\hline 4. & $\begin{array}{l}\text { Through } \\
\text { Society }\end{array}$ & 5 & 10 \\
\hline 5. & $\begin{array}{l}\text { Through } \\
\text { Middlemen }\end{array}$ & 10 & 20 \\
\hline & \multicolumn{1}{|c|}{ Total } & $\mathbf{5 0}$ & $\mathbf{1 0 0}$ \\
\hline
\end{tabular}

Source: Primary Data

From the above table it is very clear that $40 \%$ of the farmers have come to know the price of cotton through news paper; $20 \%$ through middlemen; $18 \%$ of the respondents get the information regarding the price through television; and $12 \%$ of the respondents through radio; and the remaining $10 \%$ of farmers come to know through society.

It is clear from the above table that most $(40 \%)$ of the farmers come to know the market price details with help of newspaper.

\section{FINDINGS}

1. From the above analysis it is revealed that most of the farmers are cultivating cotton on the own land.

2. It is worthwhile understood that $70 \%$ of the respondents are cultivating cotton in throughout the year.

3. It is interesting to note that most $80 \%$ of the respondents prefer summer season for cotton cultivation in the study area.

4. To testing the hypothesis, it is proved that the season for cotton cultivation is playing a dominant role in yield of cotton per acre in the study area.

5. It is evident from the above analysis that majority of $(50 \%)$ the farmers face lack of finance, for cotton cultivation.

6. It is clear from the above analysis that $36 \%$ the cost is incurred for picking charges and plucking charges. The above details are presented in the following diagram

7. It is cleared that from the above table indicates the $72 \%$ of the farmers to sale of cotton immediately.

8. It is clear from the above table that most $(40 \%)$ of the farmers come to know the market price details with help of newspaper.

\section{SUGGESTIONS}

To overcome the various problems that has been identified by this empirical study. The researcher has pleased to give the following suggestions.
1. Most of them are found to own a land having a size of less than 5 acres, which is not an economical size. Therefore, it is suggested that the cultivators can form a co- operative farming society and undertake cotton cultivation jointly. Since the rainfall is less in Srivilliputtur Area, the farmers can go for cotton cultivation on a large scale on a co- operative basis, so as to achieve high yield per acre at low cost and by providing drip irrigation facilities.

2. To solve the problem of inadequate finance, it is suggested that the farmers shall come forward to make use of the liberal loan facilities offered by rural banks and commercial banks. Now, nobody has availed the loan facilities offered by rural banks.

3. To solve the problem of higher wages, it is recommended that at least charges like plucking, and weeding may be paid on the basis of the piece rate system as well as time rate system. The piece rate system is conspicuously absent in the study area.

4. To know the prices prevailing in different markets, it is suggested that the village panchayat shall take efforts to construct a common reading room where all- important Tamil daily newspapers may be kept for the benefit of the villagers. It would help them to ascertain the market prices in different places besides increasing their literacy level to some extent. It is also suggested that the farmers may adopt grading technique so that higher prices may be fixed for quality produces.

\section{CONCLUSION}

Only few of the cotton cultivators in the study area have prospered enough by their painful efforts. But they are just islands compared with the oceans of the hard-pressed farmers. The majorities are still prisoners of the poor market condition. The Government should invest more in providing cold storage, warehouses, rural roads, electrification, hybrid seeds, pesticides and marketing. If the farmers (cotton cultivators) are offered with more benefits, the Indian cotton cultivators will do great works. Otherwise, they would be pushed to the poverty further.

The necessary government steps will only provide good improvement in cotton production and marketing in the study area and can enhance the standard of living of the farmers. Will the government come forward to implement the suggestions?

\section{REFERENCES}

1. Banumathy.S, "Indian Journal of Marketing, Jan 2005 Page No. 27, VOL - XXXV.

2. Rajan Nair.N, "Marketing" New Delhi, Sultan chand \& son, 1983, Page No. 3.74.

3. Vijay P. Sharma Productivity, Vol.39,No.3, October - December1998 P. No.483

4. Prabhar rao J.V. "Marketing efficiency in agricultural Products" Himalaya Publishing House, 1985, Page No. 19.

5. Prabhar rao J.V. "Marketing efficiency in agricultural Products" Himalaya Publishing House, 1985, Page No. 19.

6. Sureshkumar and Dr. Anand singh, Kishan world, May- August 2003 P.No.45.

7. Nagarajan.S.S, "Kisan world", December 2007, Page No. 13.

8. Final Report of Famine Enquiry commission - 1948, Page. No. 129.

9. Pyle, J.F. "Principle of Marketing", New York, McGraw - Hill book, 36, Page. No.24. 
10. Converse, Hugey and Mitchell,"Elements of marketing”,1983 page No.

11. Marchland, D., and Varadharajar, B. An Introduction to Marketing", Vikas publishing House pvt. Ltd. New Delhi. 1981 Page No. 304.

12. Report of the Indian committee 1919 Page. No. 236.

\section{AUTHORS PROFILE}

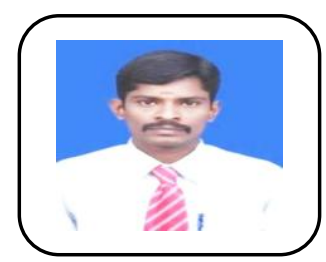

Mr.P.Ramakrishnan M.Com.,MBA.,M.Phil., SET., He is working as Assistant professor of commerce, Department of commerce, Kalasalingam Academy of Research and Education (Deemed to be University). Krishnan Koil. $\mathrm{He}$ has published in 3articles in National and international journal. He has 10 years of experience in two different colleges. 